\title{
Photovoltaic System Efficiency Enhancement with Thermal Management: Phase Changing Materials (PCM) with High Conductivity Inserts
}

\author{
*Sylevaster Kyaligonza ${ }^{(D)}$, *Erdal Cetkin (iD) \\ *Izmir Institute of Technology, Department of Mechanical Engineering, Urla, Izmir 35430, Turkey \\ (kk125sylvester@gmail.com, erdalcetkin@iyte.edu.tr ) \\ Correspondance: Sylevaster Kyaligonza, Department of Mechanical Engineering, Urla, Izmir 35430, Turkey \\ kk125sylvester@gmail.com , Phone: +256700303300
}

Received: 19.11.2021 Accepted:08.12.2021

\begin{abstract}
The electrical conversion efficiency of photovoltaic cells from solar radiation heavily depends on the cell temperature. Here we propose a novel thermal management strategy to keep the cell temperature in the same order to attain maximum efficiency. The comparative study presented is based on four solar module configurations: a conventional photovoltaic module (PVT module), a conventional module with PCM layer underneath (PVT/PCM-I), a configuration where fins embedded into PCM (PVT/PCM-II), and configuration where the bottom of the PCM layer in PVT/PCM-II was cooled via convection (PVT/PCM-III). The developed 3D numerical model is solved via ANSYS software involving the solar ray tracing radiation model for incident solar radiations and a transient melting-solidification thermo-fluid model to cater for PCM phase transition. Results from the numerical model were validated via a comparison of experimentally studied results presented in the literature. After 120 minutes, results show that the conversion efficiency of PV cells becomes $16.84 \%, 18.65 \%, 18.83 \%$, and $18.98 \%$ after 120 minutes for PVT module, PVT/PCM-I, PVT/PCM-II, and PVT/PCM-III with an inlet velocity of 3m/s, respectively. For the respective configurations, the specific electrical power per unit area produced reaches $75.30 \mathrm{~W} / \mathrm{m} 2,83.39 \mathrm{~W} / \mathrm{m} 2,84.19 \mathrm{~W} / \mathrm{m} 2$, and $89.42 \mathrm{~W} / \mathrm{m} 2$ for solar radiation of $540 \mathrm{~W} / \mathrm{m} 2$ and $26^{\circ} \mathrm{C}$ ambient temperature. Results reveal that a $5 \mathrm{~mm}$ increase in the fin height for PVT/PCM-II results in a $0.22 \%$ increase in efficiency while a $0.5 \mathrm{~m} / \mathrm{s}$ increase in the inlet velocity of the cooling air for PVT/PCM-III results in about $0.06 \%$ increase in efficiency.
\end{abstract}

Keywords: Photovoltaic module, Conversion efficiency, Thermal management, Phase change materials.

\section{Introduction}

Energy is 'an essential part of the modern lifestyle as it is required for production, transportation, entertainment, and all other activities. However, the conversion of energy from one form to another comes with the cost of entropy generation and environmental effects. Even though each conversion method is generating entropy, some are affecting the environment more than others such as electricity generation from nonrenewable sources (fossil fuels)[1] [2]. The effect of electricity generation on the environment and climate is minimized through the use of renewable sources among which includes biomas, hydro electricity, wind, geothermal and solar[3][4]. Even though they are environmentally friendly, they suffer from the disadvantage of low energy potential, low conversion efficiency, fluctuating characteristics, and high cost. The advancement of technology decreases and will continue to decrease the cost of $\mathrm{kWh}$ converted electricity from renewable sources. Solar energy can be harvested in two distinct ways: direct conversion into electricity (solar photovoltaic systems) and solar energy conversion into heat for heating applications or electricity generation (Solar thermal systems) [5]. Even though the conversion efficiency of solar radiation to heat is comparatively high if it is coupled with the Rankine cycle, system efficiency becomes the multiplication of Rankine cycle efficiency and heat conversion efficiency. For direct heating applications, the efficiency of solar thermal systems reaches up to $60 \%$, requiring high-temperature applications, and lower efficiency values between $12 \%$ and $20 \%$ are registered indirect power generation applications unless concentration technologies are adopted[5], [6]. Electricity is generated directly in PV cells in a low-temperature conversion process as solar radiation is received. A portion of solar radiation cannot be converted into electricity which becomes heat dissipated from the module [7]. On average, the conversion efficiency of PV cells is in the order of $26 \%$ for monocrystalline (Mono c-Si), 21\% for polycrystalline silicon cells, $21.6 \%$ for thin-film cells, $21.4 \%$, for Cadmium Telluride (Cd-Te) cells have and $11.8 \%$ for amorphous silicon cells [8]. Even though both solar energy harvesting methods have their 
advantages for specific applications, we focus on the PV cells in this paper.

Electricity generation from solar radiation is appealing because of no harmful emissions and the capability to be implemented as an off or on-grid power source. Generating electricity from the roof of houses during the day and then using electricity from the grid during the night minimize the electricity generation from other sources [9], [10]. In addition, in remote locations (without a grid) PV cells become a lowcost and reliable source if they are coupled with an energy storage unit such as a battery [10]. The PV cell conversion efficiency increased in years as their production cost has decreased. For instance, the average efficiency of monocrystalline silicon PV cells increased from $4.5 \%$ in 1953 to the present $26 \%$ efficiency while the cost has reduced by approximately $87 \%$ in the last 25 years [11]. Even though the production costs have been decreasing over the years, they are not in the desired order as the manufacturing process requires advanced techniques such as molecular beam epitaxy, sputtering, close space sublimation, and metal-organic chemical vapor deposition [8], [12]. Literature documents that only $5 \%$ to $40 \%$ of the solar radiation that falls onto the PV module is converted into electricity while the remaining portion is partly reflected and partly dissipated as thermal energy in an ideal PV module[7]. This heat raises the temperature of the cell, reducing electrical output and efficiency[13][14]. The PV cell conversion efficiency is directly related to the temperature as can be seen from Fig. 1[15]. Figure 1 shows that conversion efficiency inversely proportional to the PV cell surface temperature. Short circuit current $\left(\mathrm{I}_{\mathrm{sc}}\right)$ directly varies with changes in solar cell temperature while maximum power $\left(\mathrm{P}_{\max }\right)$ and open-circuit voltage $\left(\mathrm{V}_{\mathrm{oc}}\right)$ exhibit an inverse relationship.

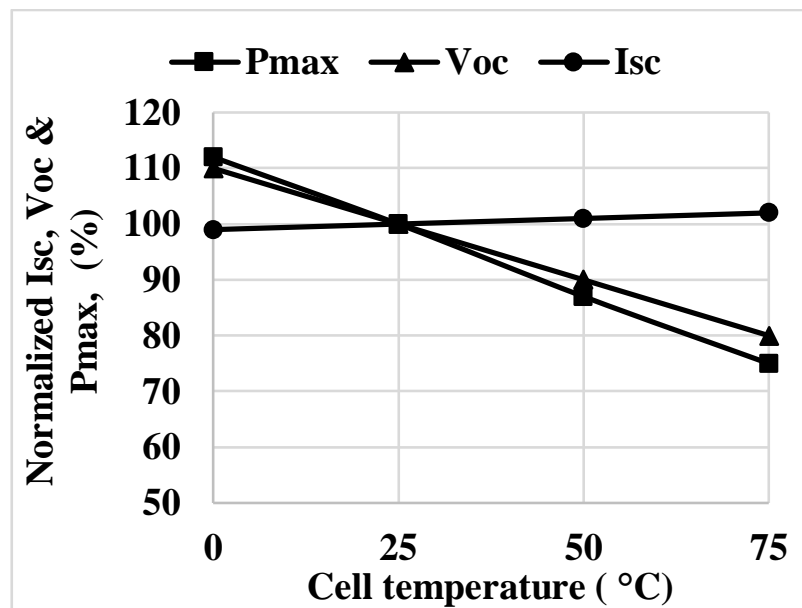

Fig. 1: Variation of solar cell performance with temperature changes[15].

Figure 1 shows that regulating the temperature of PV cells would increase conversion efficiency. Therefore, thermal management is beneficial, and it should be pursued if the energy required for it is less than the increment in the converted energy.

Thermal regulation techniques are either passive (no additional energy requirement) or active (energy required for the cooling system) and in some cases combination of both
[16]. Passive cooling techniques are mainly adopted for PV systems without concentrators or systems with low concentration[17][18]. Passively cooled PV systems are costeffective but exhibit low-performance efficiencies. Passive cooling mainly involves two approaches: heat sinks and heat spreaders (heat dissipation plate). In the latter, a metal plate with relatively high thermal conductivity is used to evenly spread heat from sunlight to eliminate concentration on the cells to avoid non-uniform temperature distribution [19]. The use of heat sinks is well adjusted for the PV cells conversion efficiency increment as cell temperature can be kept in the desired temperature range [20][21][22]. Heat sinks are either air-cooled or liquid-cooled [23][24]. Water is mainly used as a coolant liquid despite its corrosive nature because of its abundance. Nanofluids are also used in active cooling and the increment in the output power is much greater in comparison to the cost of heat transfer enhancement[25]. The adoptation of Phase changing materials (PCM) for thermal management is because of their two primary characteristics: phase change occurs at constant temperature and latent heat for melting is much greater than the sensible thermal capacitance of substances[26]. Manish K., 2008 [27] categorizes these materials as organics, inorganics, and a eutectic combination of materials. Inorganic PCMs face the setback of phase separation. This occurs because of incongruent melting and variation in densities of inorganic salts and water. Phase separation can be eliminated by mechanical stirring, PCM encapsulation, use of gelling agents, extra-water principle and property modification In addition to phase separation, most phase change materials face problems of super-cooling or subcooling, low thermal conductivity, poor thermal stability, and corrosion. Kavendra et al [28] explain the remedies to the above problems.

Due to low thermal conductivities of organic PCMs, nonuniform temperature distribution during a phase change (melting/solidification) are created[29]. Therefore, heat transfer enhancement such as addition of surfaces[30] is required to eliminate hot spots and achieve uniform temperature distribution [31]. This study proposes a combined thermal management system to maximize PV conversion efficiency which can be applied in distinct conditions and locations. The thermal regulation technique discussed in this study keeps the temperature of the solar cells uniform along the surface of the module thus improving cells' electrical conversion efficiency and lowers the induced thermal stresses on the PV module surface due to uniformity of surface tempature. Unlike the literature, this paper uncovers a novel approach to modeling solar cells via solar ray tracing. This modeling technique allows the effect of convection heat transfer and incident solar radiations to be modeled on the PV surface simultaneously. Furthermore, modeling of a smart system for concentrated solar power (CSP) that assumes that radiations perpendicularly incident the panel to be uniformly distributed is modelled by this techique.

\section{Materials and methods}

The Monocrystalline photovoltaic module of $500 \mathrm{~mm} \times$ $500 \mathrm{~mm}$ surface area was selected to document how thermal regulation affects energy conversion efficiency. 
The PV panel includes a layer of tempered glass, solar cells encapsulated between two layers of ethylene-vinyl acetate (EVA) and the back sheet made of Polyvinyl fluoride (PVF) respectively, from the top to bottom [32].

The composite module is enclosed within an aluminum enclosure. The transparent EVA lamination prevents humidity to affect cells and dirt from penetrating as well as helping cells to withstand shocks and vibration due to wind (float between the glass plate and the back sheet). The metal rear contact provides mechanical strength, improves resistance to weathering, and provides electrical insulation of the cells [33]. The thermophysical properties of module layers and the studied PCM (RT35) are presented in Table 1. These properties are assumed to remain constant with variation in both temperature and pressure as the variation in temperature would be limited due to thermal management and the pressure variation would also be small enough in distinct sites. In the numerical simulation, the PV module is considered as a single layer with thermal properties of crystalline cells [15]. Ethylene Propylene Diene Monomer (EPDM) is used to provide insulation[34]. An organic PCM ( RT35) whose melting range is close to the Standard Test Condition temperature was selected for this application. This type of PCM exhibits higher thermal storage capacity at an approximately constant temperature range[35].

Table 1: Material properties [27][10][35][36]

\begin{tabular}{|c|c|c|c|}
\hline Component & Parameter & Value & Unit \\
\hline \multirow[t]{7}{*}{ Glass cover } & Density, $\rho_{g}$ & 3000 & $\mathrm{~kg} / \mathrm{m}^{3}$ \\
\hline & Thickness, $\delta_{g}$ & 0.003 & $\mathrm{~m}$ \\
\hline & Specific heat, $C_{g}$ & 500 & $\mathrm{~J} / \mathrm{kgK}$ \\
\hline & Thermal conductivity, $k_{g}$ & 2 & $\mathrm{~W} / \mathrm{mK}$ \\
\hline & Emissivity, $\varepsilon_{g}$ & 0.9 & - \\
\hline & Absorptivity, $\alpha_{g}$ & 0.04 & - \\
\hline & Transmissivity, $\tau_{g}$ & 0.92 & - \\
\hline \multirow[t]{8}{*}{ Silicon layer (PV cells) } & Density, $\rho_{S C}$ & 2330 & $\mathrm{~kg} / \mathrm{m}^{3}$ \\
\hline & Thickness, $\delta_{s c}$ & 0.0002 & $\mathrm{~m}$ \\
\hline & Specific heat, $C_{S C}$ & 667 & $\mathrm{~J} / \mathrm{kgK}$ \\
\hline & Thermal conductivity, $k_{s c}$ & 148 & $\mathrm{~W} / \mathrm{mK}$ \\
\hline & Absorptivity, $\alpha_{s c}$ & 0.9 & - \\
\hline & Packing factor, $\beta_{s c}$ & 0.9 & - \\
\hline & Temperature coefficient, $\beta_{1, r e f}$ & 0.0045 & $\mathrm{~K}^{-1}$ \\
\hline & Reference efficiency, $\eta_{\text {ref }}$ & 0.2 & - \\
\hline \multirow[t]{4}{*}{ EVA } & Density, $\rho_{e}$ & 960 & $\mathrm{~kg} / \mathrm{m}^{3}$ \\
\hline & Thickness, $\delta_{e}$ & 0.0005 & $\mathrm{~m}$ \\
\hline & Specific heat, $C_{e}$ & 2.090 & $\mathrm{~J} / \mathrm{kgK}$ \\
\hline & Thermal conductivity, $k_{e}$ & 0.35 & $\mathrm{~W} / \mathrm{mK}$ \\
\hline \multirow[t]{6}{*}{ RT35 PCM } & Thermal conductivity & 0.2 & $\mathrm{~W} / \mathrm{m} \mathrm{K}$ \\
\hline & Density (solid/liquid) & $860 / 770$ & $\mathrm{~kg} / \mathrm{m}^{3}$ \\
\hline & Specific heat capacity (solid/liquid) & $1800 / 2400$ & $\mathrm{~J} / \mathrm{kgK}$ \\
\hline & Latent heat & 160,000 & $\mathrm{~J} / \mathrm{kg}$ \\
\hline & Viscosity & 0.001798 & $\mathrm{~kg} / \mathrm{m}-\mathrm{s}$ \\
\hline & Melting area & $302-309$ & $\mathrm{~K}$ \\
\hline \multirow[t]{3}{*}{ Copper } & Thermal conductivity & 400 & $\mathrm{~W} / \mathrm{m} \mathrm{K}$ \\
\hline & Density & 8933 & $\mathrm{~kg} / \mathrm{m}^{3}$ \\
\hline & Specific heat capacity & 385 & $\mathrm{~J} / \mathrm{kgK}$ \\
\hline
\end{tabular}

\subsection{Model Configurations}

The study was conducted considering 4 PV module configurations as illustrated in Fig.2. These include PVT module (a), PVT/PCM-I (b), PVT/PCM-II (c), and PVT/PCM-III (d). The modules are subjected to solar irradiance of $540 \mathrm{~W} / \mathrm{m}^{2}$, the average hourly direct solar irradiation in Uganda[36], and an air film coefficient of 8
$\mathrm{W} / \mathrm{m}^{2} \mathrm{~K}$ with an ambient air temperature of $26^{\circ} \mathrm{C}$. In PVT/PCM-I, a layer of RT35 PCM was introduced below the panel. The PCM is enclosed in a thin aluminum enclosure which is later insulated by Ethylene Propylene Diene Monomer (EPDM) sheets. In PVT/PCM-II, fins made of Copper were introduced to the PCM layer. The fins are designed as a plate heat sink of $2 \mathrm{~mm}$ thick. In PVT/PCM-III, a rectangular air duct is introduced below the entire surface of the PCM to further improve cooling. 


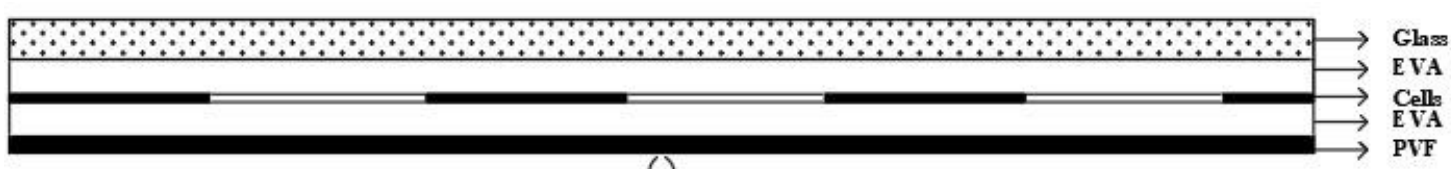

(a)

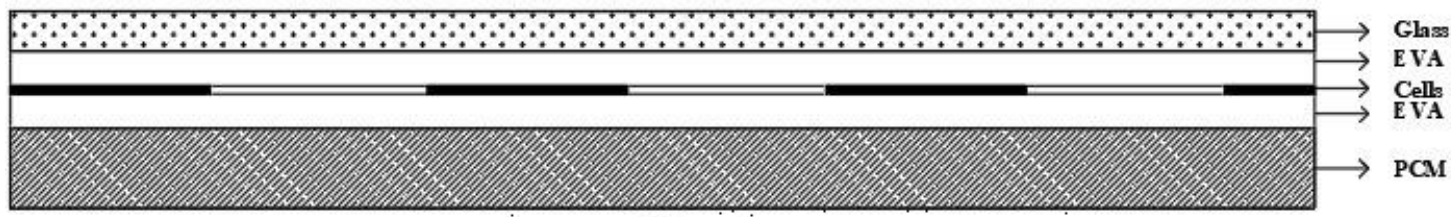

(b)

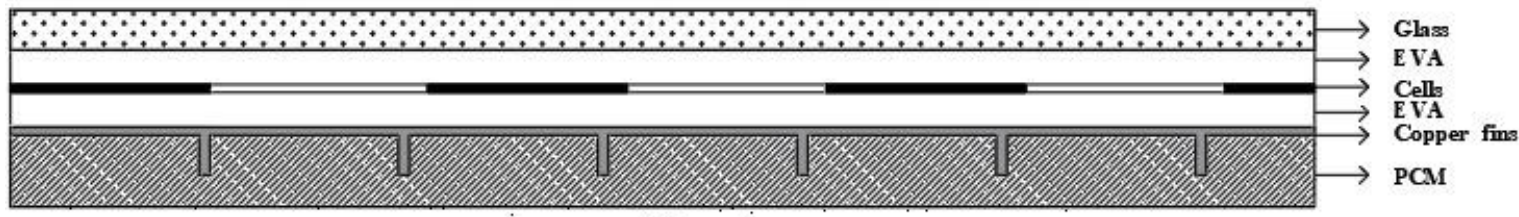

(c)

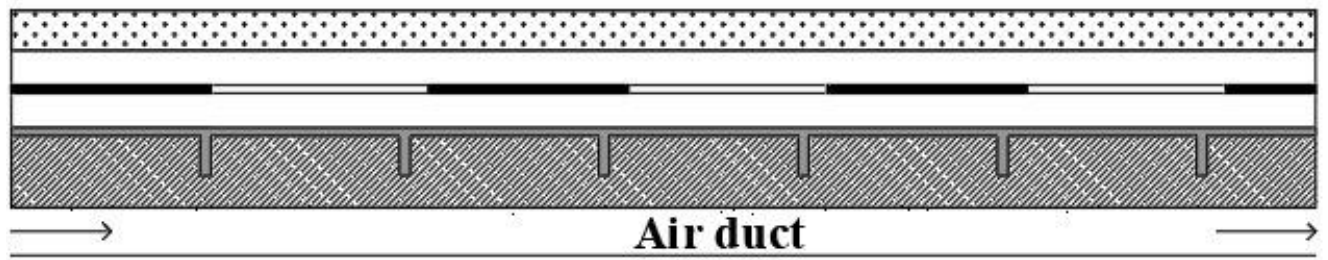

(d)

Fig. 2: Schematic cross-section of photovoltaic modules

\subsection{Model}

To cater for the phase transition of the PCM, the enthalpyporosity modelling approach was adopted. The energy balance is used as the foundation for calculating the liquid fraction in this method. The mushy zone (an area with a liquid fraction of 0 to 1 ) is introduced and handled as a "pseudo" porous medium. In this zone, the porosity and the liquid fraction are the same and varry equaly as the PCM melts[37]. The governing equations for the flow take the form below [38][39]. $\mathrm{X}$-direction momentum equation.

$\rho(\vec{V} \cdot \nabla u)=-\nabla P+\mu \nabla^{2} u+S_{x}$

Y-direction momentum equation.

$\rho(\vec{V} \cdot \nabla v)=-\nabla P+\mu \nabla^{2} v+S_{y}+F_{b}$

Z-direction momentum equation.

$\rho(\vec{V} \cdot \nabla w)=-\nabla P+\mu \nabla^{2} w$

In the above equations, $\nabla=\frac{\partial}{\partial \mathrm{x}} i+\frac{\partial}{\partial y} j$ and $\nabla^{2}=\frac{\partial^{2}}{\partial \mathrm{x}^{2}} i+\frac{\partial^{2}}{\partial y^{2}} j$. $F_{b}$ is the buoyance force which is calculated from the Boussinesq approximation [40].

$F_{b}=-\rho_{o} g\left(1-\beta_{1}\left(T-T_{o}\right)\right)$

$\beta_{1}$ is the thermal expansion coefficient while $\rho_{\text {liquid }}$ and $T_{m}$ are density and temperature respectively at the melting point. The terms $s_{x}$ and $s_{y}$ are Darcy's law momentum sink terms that cater for the reduced porosity in the partially solidified regions of the PCM[38], they are calculated from Equations (5) and (6).

$s_{x}=\frac{(1-\lambda)^{2}}{\left(\lambda^{3}+\gamma\right)} A_{m u s h} \cdot u$

$s_{y}=\frac{(1-\lambda)^{2}}{\left(\lambda^{3}+\gamma\right)} A_{m u s h} \cdot v$
Where $\lambda$ represents the fraction of the liquid PCM present in the PCM domain as it melts (liquid fraction) and $\gamma$, is a negligibly small numerical value about 0.001 [40] introduced to eliminate division errors that arise when the liquid fraction is zero. Mushy zone constant, $A_{\text {mush }}$ explains the steepness of the velocity as it reaches to zero when the material is undergoing solidification. The value of $A_{m u s h}$ depends on the morphology of the phase-changing material and takes on numerical values between $10^{3}$ and $10^{8} \mathrm{~kg} / \mathrm{m}^{3} \mathrm{~s}$. For the current study, the value of $A_{\text {mush }}$ is kept at $10^{8} \mathrm{~kg} / \mathrm{m}^{3}$ s for better prediction[38]. The energy equation for the phase changing material reduces to eq. (7) and eq. (8);

Liquid phase

$\frac{\partial}{\partial t}\left(\rho_{l} H\right)+\nabla \cdot\left(\rho_{l} \tilde{v} H\right)=\nabla \cdot\left(k_{l} \nabla T\right)+S$

Solid-phase $\frac{\partial}{\partial t}\left(\rho_{S} H\right)=\nabla \cdot\left(k_{s} \nabla T\right)$

Where $\mathrm{S}$ is the source terms. Enthalpy, $\mathrm{H}$ of the PCM is the summation of ensible enthalpy, $\mathrm{h}$, and latent enthalpy $\Delta \mathrm{H}$, and calculated from eq. (9).

$H=h+\Delta H$

$h=h_{\text {ref }}+\int_{T_{\text {ref }}}^{T} C_{p} d T$

where $T_{\text {ref }}$ is the reference temperature $\left(25^{\circ} \mathrm{C}\right)$ and $h_{\text {ref }}$ is enthalpy at $\left(25^{\circ} \mathrm{C}\right)$. The value of $\Delta H$ is expresssed in terms of the specific enthalpy of melting, $\mathrm{L}$, and is calculated from the equation (11).

$\Delta H=\lambda L$

The value of the liquid fraction $\lambda$ is defined by eq.(12) [38][41]; 
$\lambda=\left\{\begin{array}{cc}0, & \mathrm{~T}<T_{\text {solidus }} \\ \frac{\mathrm{T}-T_{\text {solidus }}}{T_{\text {liquidus }}-T_{\text {solidus }}}, & T_{\text {solidus }}<T<T_{\text {liquidus }} \\ 1, & T>T_{\text {liquidus }}\end{array}\right.$

In solidification and melting, the equation

$\lambda=\frac{\mathrm{T}-T_{\text {solidus }}}{T_{\text {liquidus }}-T_{\text {solidus }}}$ is referred to as the lever rule. For a complete melting-solidification cycle, PCM thermal conductivity varies according to the relation presented in eq.(13)[40].

$k_{p c m}=\left\{\begin{array}{lr}k_{s}, & T<T_{\text {solidus }} \\ \frac{k_{s}+k_{l}}{2}, & T_{\text {solidus }}<T<T_{\text {liquidus }} \\ k_{l}, & T>T_{\text {liquidus }}\end{array}\right.$

For proper thermal modeling, the assumptions presented by Arifin et al [32] must be put into consideration. Heat transfer through the PV module layers is governed by heat balance equation as discussed by Nasef et al [40] and Slimani et al [42].

The cell's conversion efficiency, $\eta_{s c}$ is calculated from the Evans Florschuetz cell's efficiency equation, eq.(14)[43]. $T_{s c}$ is the cell's temperature and $T_{r e f}$ is the reference temperature considered as $25^{\circ} \mathrm{C}$ at STC.

$\eta_{s c}=\eta_{T_{\text {ref }}}\left[1-\beta_{1 \text { ref }}\left(T_{s c}-T_{\text {ref }}\right)\right]$

The modified energy equations were applied to the PV cell to estimate total, thermal and electrical energy. Modifications on these equations were carried out by Cox and Raghuraman[44]. The total energy, $E_{C}$ that the cell absorbs without effects of interreflection of solar irradiation between the various surfaces of the module and thermal absorption by the glass cover, is evaluated by eq. (15).

$E_{C}=\beta_{s c} \alpha_{s c} \tau_{g} G(t)$

As the solar irradiation reaches the module surface, the fraction that is converted into electrical energy. Electrical energy is calculated from eq.(16),

$E_{C E}=\beta_{s c} \eta_{s c} \tau_{g} G(t)$
A fraction of the radiation dissipated as heat constitute thermal energy, $E_{C T}=\mathrm{E}_{\mathrm{C}}-\mathrm{E}_{\mathrm{CE}}$ which is calculated from eq. (17);

$E_{C T}=\left(1-\frac{\eta_{s c}}{\alpha_{s c}}\right) \beta_{s c} \alpha_{s c} \tau_{g} G(t)$

The rate at which the back sheet layer absorbs the solar energy after successive transmission through the module layers given by the relation in eq.(18);

$E_{T}=\tau_{g}\left(1-\beta_{s c}\right) \alpha_{T} G(t)$

The principle of energy conservation can now be expounded on each component of the PV module as in eq.(19).

$\left(1-\frac{\eta_{s c}}{\alpha_{s c}}\right) \beta_{s c} \alpha_{s c} \tau_{g} G(t)+\tau_{g}\left(1-\beta_{s c}\right) \alpha_{T} G(t)=q_{c}+E_{\text {loss }}$

Where $E_{\text {loss }}$, is the total energy lost to the environment from the top glass layer. Losses are either convection (free and forced) or radiation. Free convection occurs near the surface of the glass layer as a natural buoyance force as temperature of air increases. Forced convection is a result of wind. Losses are calculated using eq.(20).

$E_{\text {loss }}=h_{g}\left(T_{g}-T_{a m b}\right)+\varepsilon_{g} \sigma T_{g}{ }^{4}-\alpha_{g} \sigma\left(T_{a m b}-6\right)^{4}$ (20)

$h_{g}$ is convection heat transfer coefficient of the layer of glass[45] while $T_{g}$ and $\varepsilon_{g}$ are the temperature and emissivity of the glass layer. The quantity $\left(T_{a m b}-6\right)^{\circ} \mathrm{C}$ is sky temperature, and $\sigma$ is the Stefan-Boltzmann constant $\left(\mathrm{W} / \mathrm{m}^{2}\right.$ $\left.\mathrm{k}^{4}\right)$. Convection heat transfer iscalculated from eq.(21).

$h_{g}=1.247\left(\left[T_{g}-T_{a m b}\right] \cos \theta\right)^{\frac{1}{3}}+2.658 V_{w}$

Where, $\theta$, is the angle of tilt of the PV module. $\theta=0^{\circ} \mathrm{C}$ for the current study.

The value of $q_{c}$, is estimated by Newton's law of cooling and calculated from Eq. 22 .

$q_{c}=h_{B}\left(T_{b}-T_{a m b}\right)$

$h_{B}=2.8+3 V_{w}[46]$

Where, $T_{b}$ is the temperature of the back sheet layer and $V_{w}$ is the wind velocity.

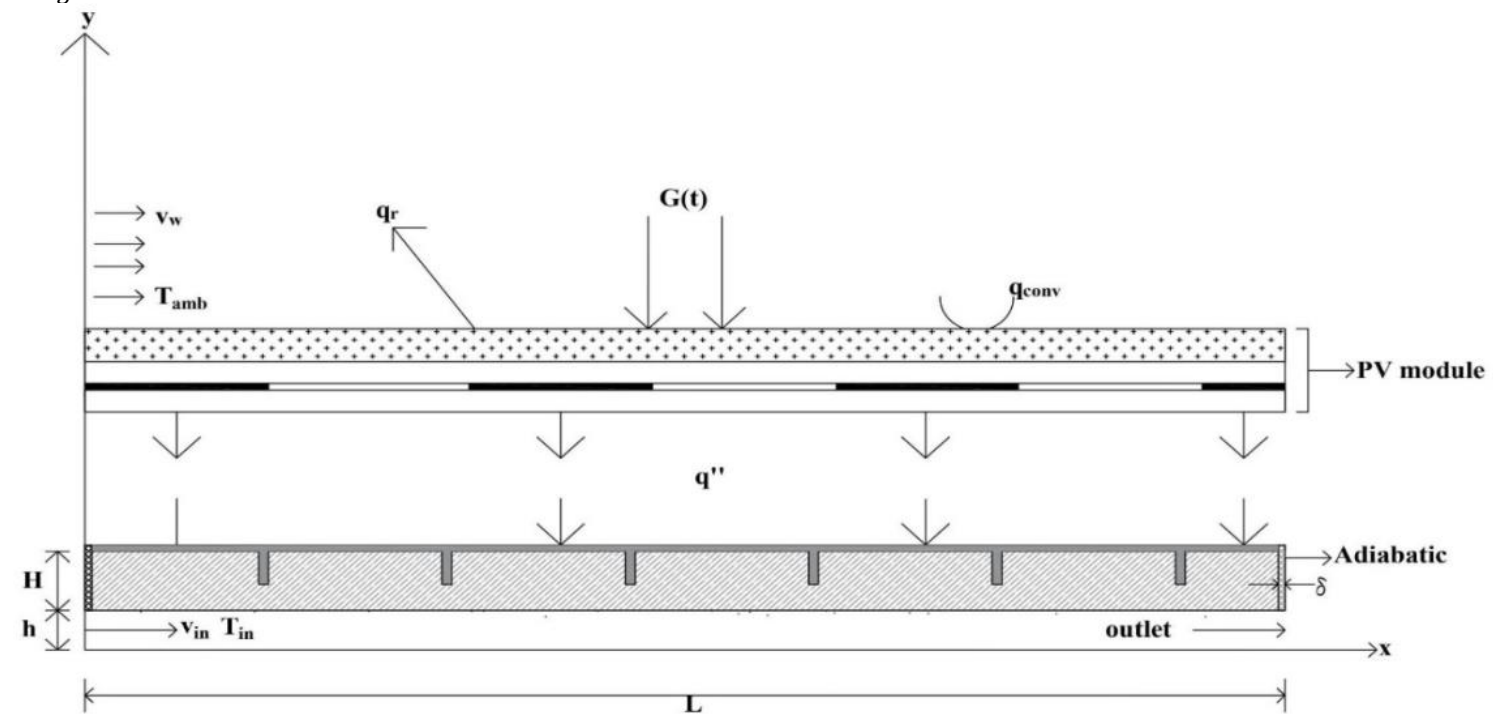

Fig. 3: Schematic cross-section of configurations with boundary conditions 


\subsection{Boundary conditions}

As radiation strikes the surface of the PV module, a fraction, $\boldsymbol{q}_{r}$ is reflected. The quantity $\boldsymbol{q}_{\text {conv }}$ caters for convection and radiation losses on the PV module surface. PCM domain. Ethylene Propylene Diene Monomer (EPDM) thickness $\delta \mathrm{mm}$ is used to provide insulation[34] of the PCM domain (Fig.3). At PCM-metal interfaces conservation of energy is satisfied.

$\boldsymbol{k}_{\text {alm }} \frac{\partial T}{\partial y}=\boldsymbol{k}_{\text {pcm }} \frac{\partial T}{\partial y}$

At $y=(H+h) m m$ heat flux from the module is received by the copper domain as

$q^{\prime \prime}=-\left.k_{\text {copper }} \frac{\partial T}{\partial y}\right|_{\mathrm{y}=\mathrm{H}+\mathrm{h}}$

At the air inlet of the cooling channel, the velocity inlet bounday conditions is assigned.

$u(0, y)=U_{\text {in }}, \quad v(0, y)=0, \quad T(0, y)=T_{\text {in }}$

A pressure outlet is assigned at the air outlet where the gauge pressure is zero $(0)$

No-slip boundary conditions were imposed on the air-metal interface in the air duct.

At $(y=0,0 \leq x \leq l)$, the boundary condition is:

$\left.k_{\text {air }} \frac{\partial T}{\partial y}\right|_{x, 0}=h_{B}\left(T_{a m b}-T_{(x, 0)}\right)$

where, $T_{a m b}$ is the ambient air temperature and $h_{B}$ is the heat transfer coefficient from the rear end to the surrounding in $\mathrm{W} / \mathrm{m}^{2} \mathrm{~K}$.

The developed computational models were subjected to the set boundary conditions and solved using a CFD software ANSYS 2020 R1 based on finite element techniques. The drawn computation domains were discretized in the $3 \mathrm{D}$ coordinate using ANSYS geometry design modeler and mesh generation software workbench. After defining the boundary surfaces, the generated mesh was exported to the fluent software. Irradiation analysis is based on solar ray tracing with the sun normal to the surface of the module (smart system) and assuming that the radiation incident on the panel is uniformly distributed[38][16]. The study was conducted considering 4 PV module configurations namely PVT module, PVT/PCM-I, PVT/PCM-II, and PVT/PCM-III. PVT module was executed in fluent by adding an air duct underneath and using a very small inlet velocity representing a low convection heat transfer coefficient thus approximating the flow to be stagnant. PVT/PCM-I and PVT/PCM-II were executed by activating the melting and solidification model to enable the melting of RT35 phase-changing material. The turbulent Realizable Kepsilon model with standard wall functions was adopted to model the cooling air. The pressure correction equation was solved using the PREssure STaggering Option (PRESTO) scheme, and the semi-implicit pressure-linked equation (SIMPLE) algorithm was employed for pressure-velocity coupling. The momentum and energy equations were solved using the quadratic upwind differencing (QUICK) scheme. All transient simulations were executed with the first-order implicit transient formulation. The above methods were suggested by M.Emam et al[38] for a better correlation between numerical and experimental data. For the rectangular duct, the hydraulic diameter $D_{H}$ approximates to $0.10714 \mathrm{~m}$ and the Reynolds numbers, $R_{e}$ was found to be 7104,14207 , and 21311 for $1 \mathrm{~m} / \mathrm{s}, 2 \mathrm{~m} / \mathrm{s}$, and $3 \mathrm{~m} / \mathrm{s}$ inlet air velocity while the turbulent intensity I was calculated as $5.5 \%, 4.8 \%$, and $4.6 \%$ for the respective

\subsection{Process and Model validation}

The numerical simulation of the PV module was validated by comparison again the experimental conducted by $\mathrm{M}$. Sardarabadi et al using weather data for Ferdowsi University of Mashhad, Mashhad, Iran [47].

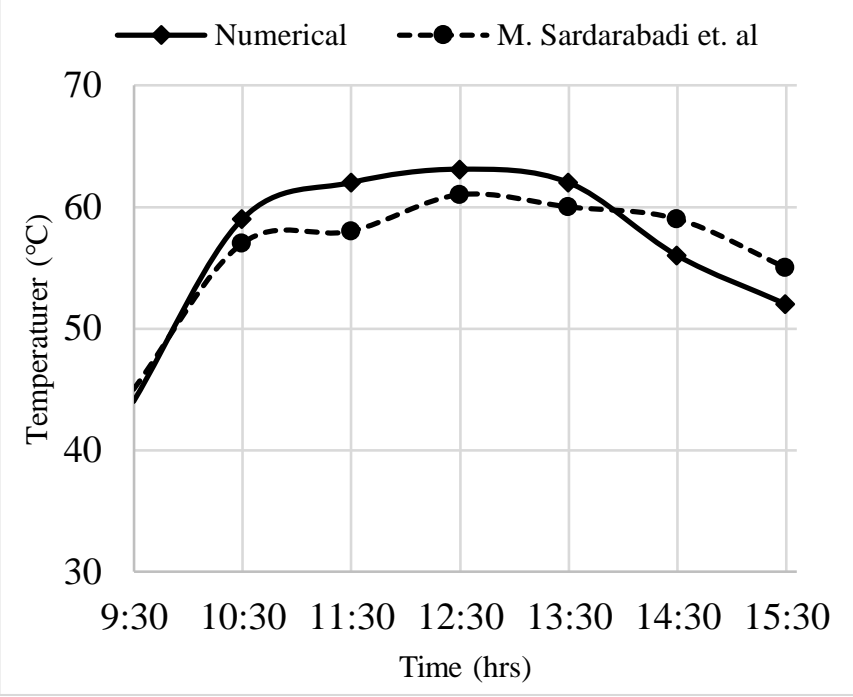

Fig. 4:Experimental and numerical results for PV-module.

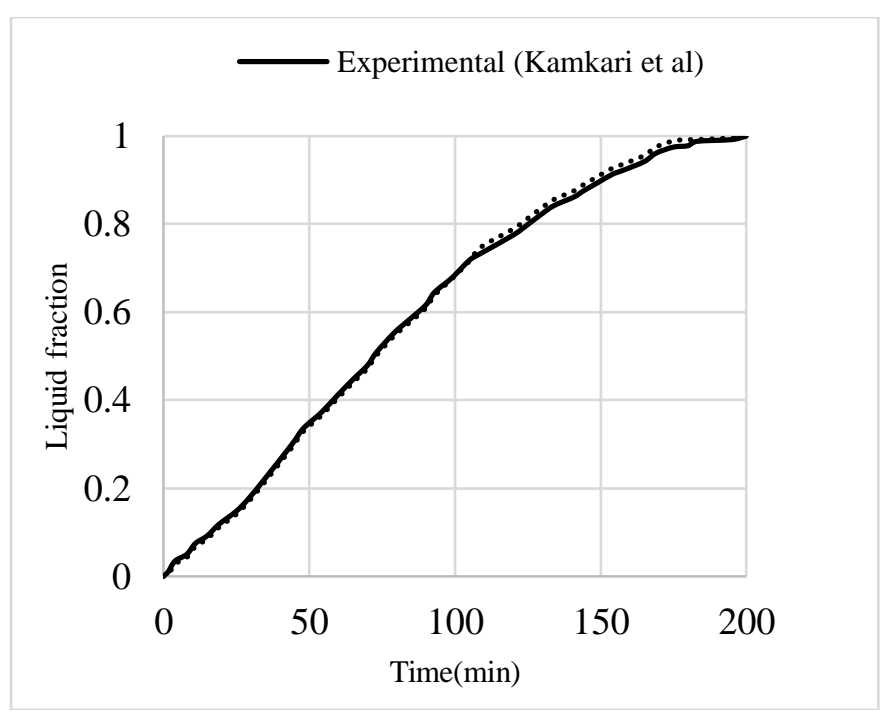

Fig 5: PCM Liquid fraction versus simulation time.

Due to the long computation time, only data for 7 data points are illustrated in Fig.4. The total difference between the results from the current numerial simulation and experimental results presented by M. Sardarabadi et al was found to be $3.1^{\circ} \mathrm{C}$. It should be noted that the discrepancy in the result may be due to the assumptions during modeling and experimental errors.

The PCM domain is validated using experimental results from Kamkari et al.2014[29]. Kamkari et al investigated the effect of a varrying inclination angle on melting rate of a 
lauric acid phase changing material in a rectangular enclosure. A $50 \mathrm{~mm}$ by $120 \mathrm{~mm}$ by $120 \mathrm{~mm}$ inner dimensional container was used in the study. A constant temperature heat exchanger was used to keep the right side of the PCM encloser at a temperature of $70^{\circ} \mathrm{C}$. The other walls were made of a $25 \mathrm{~mm}$ thick transparent plexiglass sheet of low thermal conductivity for easy visualization and to minimize heat losses. Further insulation was realized by the addition of $3 \mathrm{~cm}$ thick ethylene propylene diene monomer (EPDM) sheets. Sets of T-type thermocouples were employed for result realization. The resulting plot of the melt fraction against flow time was compared with the current study simulation and the same conditions and parameters. The graphs as shown in Fig.5 exhibited a better agreement. It should be noted that the small discrepancies between the results may be because of variations in other environmental conditions in which the experiment was performed.

\subsection{Mesh independence test.}

To obtain accurate and precise results, the mesh independency test has been conducted for PVT/PCM-I using the current study's data. The maximum cell temperatures for three computational meshes of element size $0.005,0.004$, and 0.003 and 60,000, 125,000 and 278,890 number of elements were $333.6 \mathrm{~K}, 333.1 \mathrm{~K}$, and $333.1 \mathrm{~K}$ respectively after one hour. A mesh of element size $0.003 \mathrm{~m}$ was selected for this study.

\section{Results and discussion}

\subsection{Solar flux distribution}

In this work, a novel approach for modeling the incident solar radiation based on solar ray tracing (path-tracing) was presented. The solar radiation was treated perpendicularly incident on the solar module. The reflected, transmitted, and absorbed solar flux are presented in Table 2.

Table 2: Solar radiation distribution.

\begin{tabular}{lll}
\hline & $\begin{array}{l}\text { Visible solar flux } \\
\left(\mathrm{W} / \mathrm{m}^{2}\right)\end{array}$ & $\begin{array}{l}\text { Infrared solar flux } \\
\left(\mathrm{W} / \mathrm{m}^{2}\right)\end{array}$ \\
\hline Absorbed & 163.458 & 163.458 \\
Reflected & 52.542 & 52.542 \\
Transmitted & 54 & 54 \\
\hline
\end{tabular}

Only $20 \%$ of the incident $540 \mathrm{~W} / \mathrm{m} 2$ was transmitted, $19.56 \%$ reflected while $60.54 \%$ was absorbed. Most of the radiation occurs between visible a light region of $400 \mathrm{~nm}$ to $700 \mathrm{~nm}$ for an air mass of Zero (0). For this reason, solar cells must absorb as much energy as possible in the visible region of the solar radiation spectrum[8]. The biggest fraction of the absorbed infrared radiation attributes to the heat on the solar module[48]. The module produces $326.916 \mathrm{~W} / \mathrm{m}^{2}$ of solar heat flux.

\subsection{PV Module Surface temperature}

A conventional photovoltaic system (PVT module) was modeled for comparison purposes to investigate the effect of the recommended cooling mechanism on the PV cells. The analytical solution to the configurations involves the application of energy balance equations on all PV layers exposed to solar irradiation. Numerically, maximum temperature of the solar cell surface in the conventional PVT module was found to be $60.1^{\circ} \mathrm{C}$. This serves as a reference for analysis. Fig. 6 presents the temperature contours for the four module configurations under study.

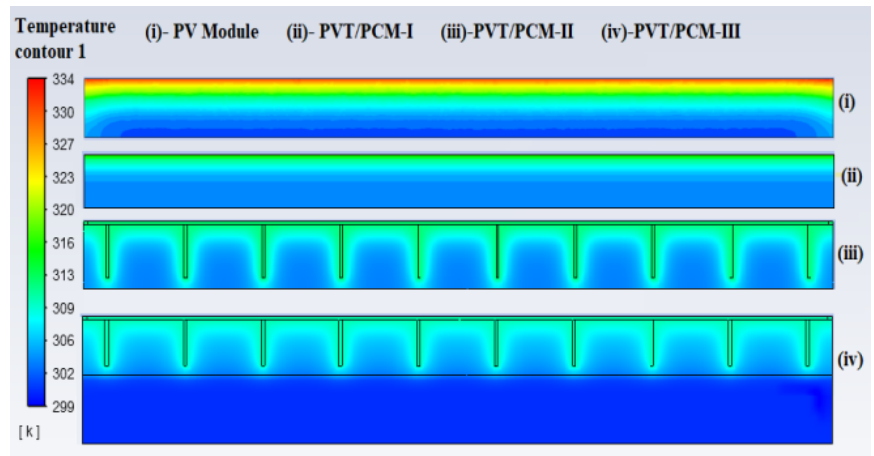

Fig. 6: Temperature contours for module configurations (After 120 minutes).

When a pack of RT35 PCM was added to the PV panel, the surface temperature was reduced by approximately $33.4 \%$ (Fig.7). When the incident solar radiation strikes the surface of the PV, its temperature raises. Eventually surface of the PCM in contact with the rare end of the module receives heat energy and at a particular point, the PCM starts melting absorbing thermal energy from the module[49]. The heat energy that would raise the PV temperature is used in a phase transition. Melting continues so long as the module is exposed to solar radiation. As the module temperature falls below the melting point, the PCM starts solidifying releasing thermal energy to the PV module. This phase transition provides a useful effect to efficiency enhancement in PV cells. The introduction of high conductivity copper fins in the PCM, as in PVT/PCM-II increases the surface area over which heat transfers. This increases the heat transfer rate inside the PCM[50], thus enhancing their thermal energy absorption capacity. Fins also act as pressure release passage for molten PCM[31]. In this study, a 5\% reduction in surface temperature was registered by embedded fins in the PCM domain. Furthermore, a $5 \mathrm{~mm}$ increase in the fin height resulted in a minimal drop of about $0.7 \%$ in the surface temperature.

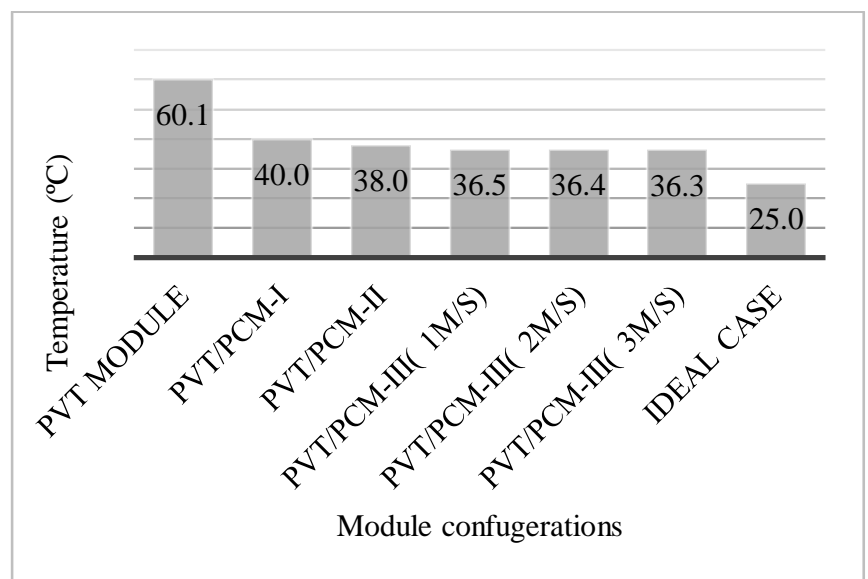

Fig. 7:Surface temperature for the respective configurations.

For PVT/PCM-II, a further increase in the magnitude of solar irradiation or a change in ambient air temperature may at a particular point change the liquid fraction of the PCM to entirely 1, as shown in Fig. 13, thus no further thermal energy 


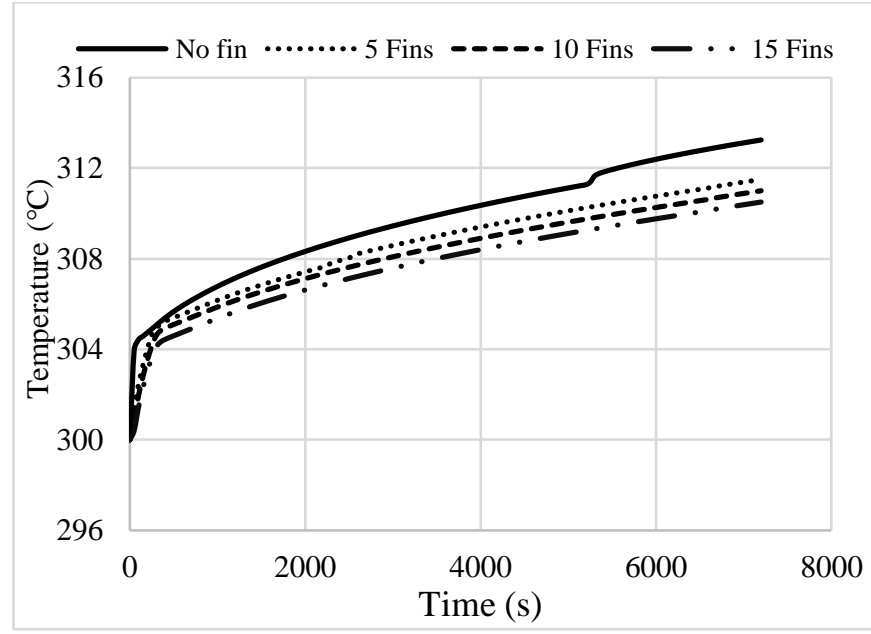

Fig.8: Solar cell surface temperature variation with fin number.

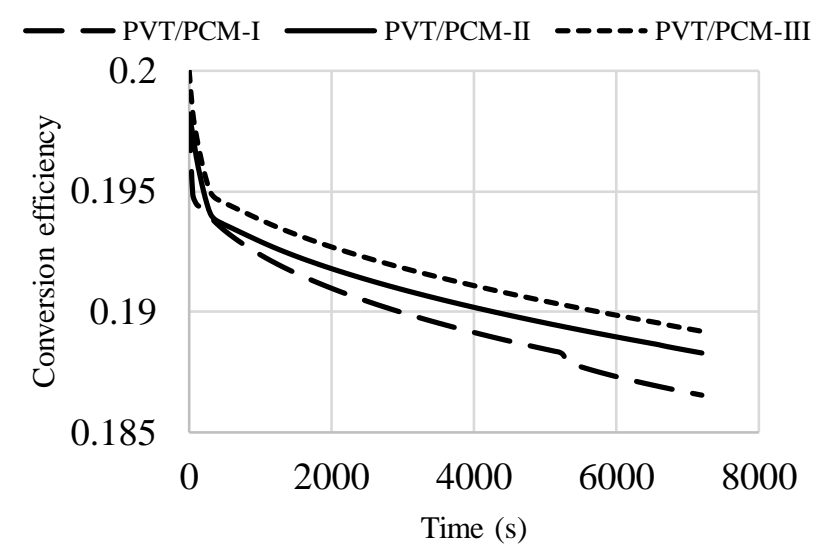

Fig. 10: Solar cell electrical conversion efficiency against computation time.

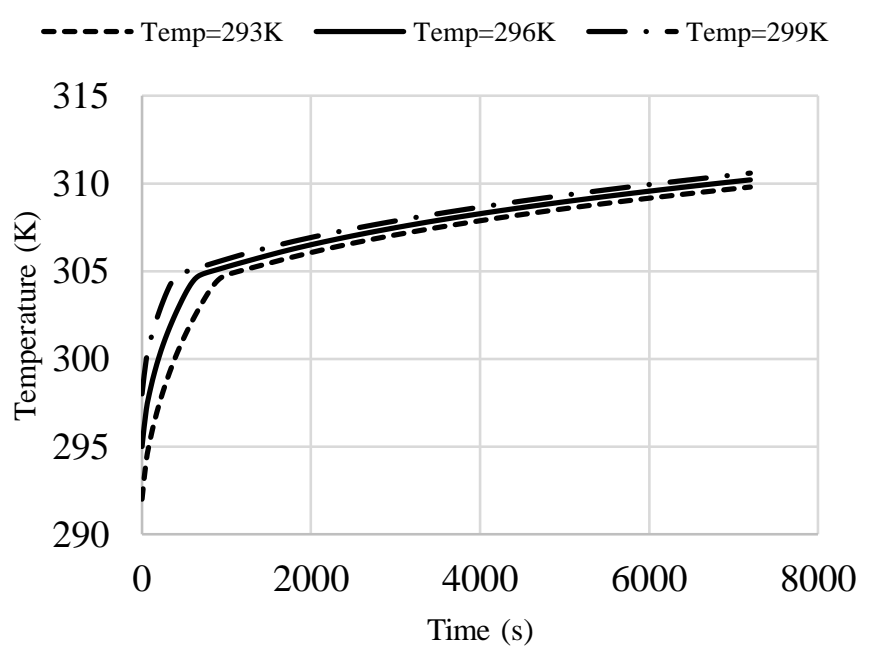

Fig. 12: Influence of temperature of inlet cooling air on PV cell temperature.

will be absorbed. At this point, the PCM acts as a heat source, contributing to the rise in the cell temperature. It was, therefore, important to cool the rear surface of the PCM as in PVT/PCM-III. The cooling effects play two roles: keeping the

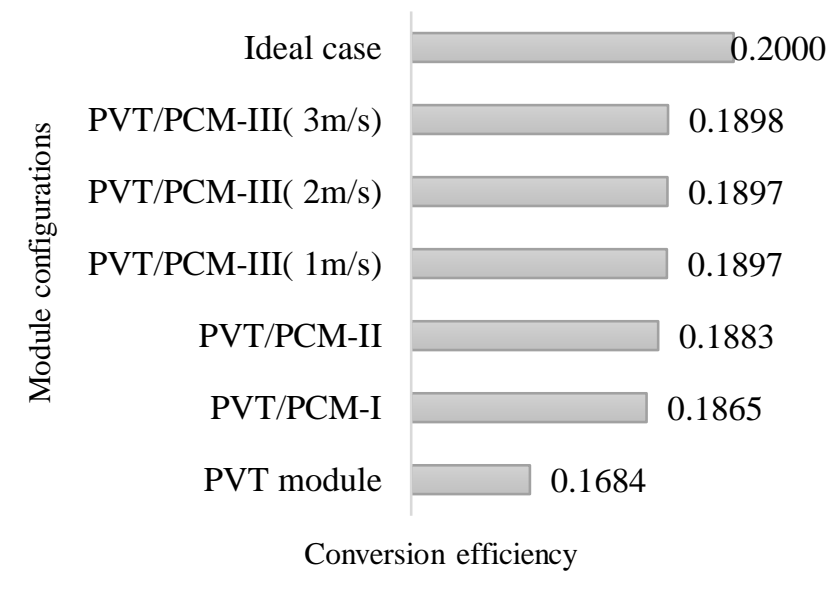

Fig.9:Electric conversion efficiencies for PV configurations.

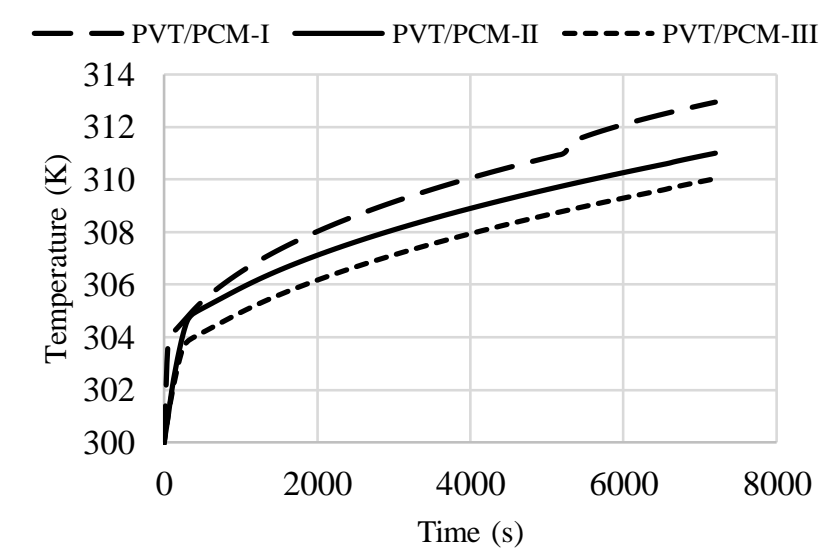

Fig. 11: Comparison of solar cells' temperature profile for time-dependent configuration.

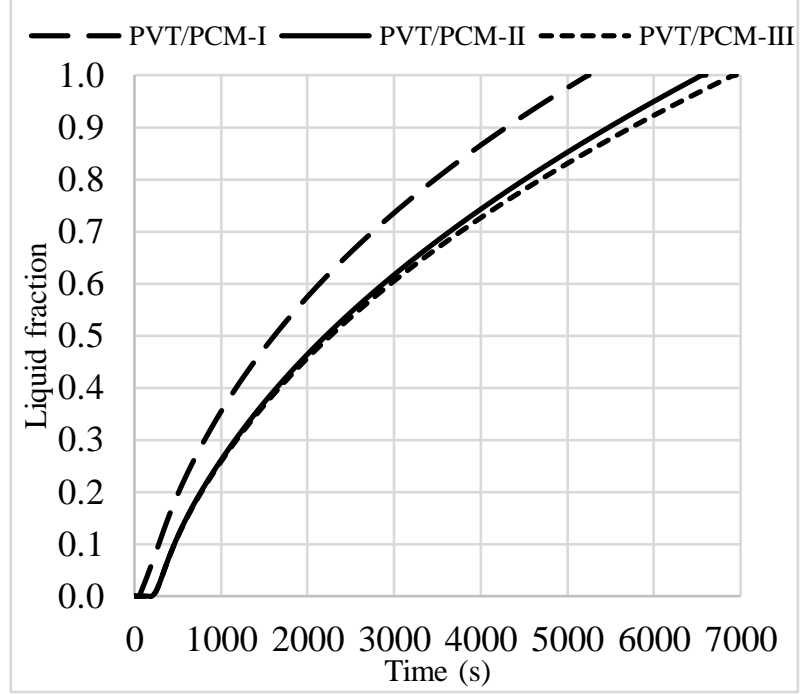

Fig.13: Comparison of PCM melt fraction for various Module configurations.

value of the liquid fraction less than 1 , thus retarding complete phase transition and contributing to a further reduction of PV surface temperature by $4.5 \%$. A unit increment in the inlet air velocity resulted in a $0.27 \%$ fall in the cell temperature. 


\subsection{Optimization of the number of fins.}

The thermal response of PVT/PCM-III for various numbers of fins in the PCM domain is presented in Fig.8. As expected, a reduction in surface temperature was observed as fins are increased. Temperature reduction is as a result of increased area on which heat transfer occurs. After 15 fins, however, the rate of temperature reduction was minimal. Further addition of fins would increase the overall system weight and hence the cost. Therefore, the optimal range of fin numbers for an observable temperature reduction is 10-15 fins. The maximum number of fins was chosen as 10 for this study.

\subsection{Effect of solar cell surface temperature on power production.}

The energy balance equations, Eqs. 15, 16, and 17 for the Photovoltaic module modified by Cox and Raghuraman [5] [44] were applied to estimate the total absorbed energy, electrical energy, and thermal energy. At standard test conditions (STC) [15], a performance of $20 \%$ can be expressed as electrical energy production of $200 \mathrm{~W} / \mathrm{m}^{2}$. For the studied module under the studied climatic data, the specific electric power produced is $75.3 \mathrm{~W} / \mathrm{m}^{2}, 83.39 \mathrm{~W} / \mathrm{m}^{2}, 84.19$ $\mathrm{W} / \mathrm{m}^{2}$, and $89.42 \mathrm{~W} / \mathrm{m}^{2}$ for the respective module configurations. The specific thermal power produced for the respective configuration as a function of surface temperature includes $327.11 \mathrm{~W} / \mathrm{m}^{2}, 319.02 \mathrm{~W} / \mathrm{m}^{2}, 317.53 \mathrm{~W} / \mathrm{m}^{2}$, and $312.98 \mathrm{~W} / \mathrm{m}^{2}$. Thermal power reduction of about $2.5 \%, 3.0 \%$, and $4.3 \%$ were registered by opting PVT/PCM-I, PVT/PCMII, and PVT/PCM-III respectively over PV Module configuration.

\subsection{Effect of cell surface temperature on the electrical conversion efficiency}

Solar cell electricity conversion efficiency was calculated using Evans Florschuetz PV efficiency equation Eq.14 [43]. For the time-dependent cases, the variation of solar cells' electrical conversion efficiency with time is presented in Fig.10. Conversion efficiency varies inversely with temperature. Efficiency value in PVT/PCM-III is always greater than that for all other configurations. For the respective module configurations, the efficiency reached $16.84 \%$, $18.56 \%, 18.83 \%$, and $18.98 \%$ as illustrated in Fig.9. A percentage increase in efficiency of $10.75 \%, 11.82 \%$, and $12.71 \%$ was registered by using PVT/PCM-I, PVT/PCM-II, and PVT/PCM-III respectively over PVT module configuration.

\subsection{The temperature profile of the PV cells under different configurations.}

A plot of cell temperature against time, observing the rate at which the temperature of the solar cells raises over time is shown in Fig. 11. It is observed that the temperature of the PV Cells increases steeply to about $303 \mathrm{~K}$ for the first 200 seconds for PVT/PCM-I. Within this range, the PCM is still solid. At $303 \mathrm{k}$, the heat energy that would raise the cells' temperature is absorbed by the melting PCM. This lowers the rate at which surfaces temperature increases for the remaining 7000 seconds. The rate at which temperature rises in PVT/PCM-II is higher than that in PVT/PCM-III for the entire 7200 seconds of the simulation time. This is attributed to the additional cooling effect of the coolant air in the duct at the rear end of the PCM.

\subsection{Effect of inlet cooling air temperature on cell temperature.}

A reduction in the air temperature at the inlet in PVT/PCM-III reduces the PCM rate of melting thus enhancing its thermal energy storage capacity. From Fig.12, it is evident that a $1 \%$ reduction in coolant air temperature results in a nearly $3{ }^{\circ} \mathrm{C}$ reduction in the cell temperature.

\subsection{Effect of module configuration on PCM melting rate.}

Figure 13 compares the melt fractions of RT35 for the different module configurations within the first 2 hours of exposure to solar radiation. For PVT/PCM-I, the PCM starts melting after the first 100 seconds. Between the interval of 0 to 100 seconds, the PCM is entirely solid as the heat energy is absorbed by the PV module layers. For PVT/PCM-II and PVT/PCM-III, melting commences after 200 seconds and gradually increases up to a complete phase change. A complete phase transition occurs after 5250 seconds, 6600 seconds, and 6950 seconds for PVT/PCM-I, PVT/PCM-II, and PVT/PCM-III, respectively. Thus, the melting rate is higher in PVT/PCM-I than in all other configurations. This means that PVT/PCM-III absorbs and stores more thermal energy than all other configurations.

\subsection{Effect of PCM melting temperature on cell temperature.}

The response of PVT/PCM-III towards the change in the PCM melting temperature was evaluated under the studied conditions. The rest of the thermophysical properties of the PCM were kept unaltered, and only its melting temperature varied in an appreciable range for module applications $\left(29^{\circ} \mathrm{C}\right.$, $34^{\circ} \mathrm{C}$, and $54^{\circ} \mathrm{C}$ ). For the two hours of simulation time, the results indicate that an increase in PCM melting temperature results in an increased cell temperature because of the increased melting rate. Cell temperatures of $36.3^{\circ} \mathrm{C}, 39.4^{\circ} \mathrm{C}$, and $44.1^{\circ} \mathrm{C}$ were registered for the respective melting temperature. Thus, to maximize efficiency, a PCM whose melting temperature is $29^{\circ} \mathrm{C}$ should be used.

\subsection{Amount of RT35 PCM required}

The studied PV module, Fig.6(i) produces an estimated solar heat flux of $326 \mathrm{~W} / \mathrm{m}^{2}$ for an area of $0.25 \mathrm{~m}^{2}$. This corresponds to $81.729 \mathrm{~W}$ heat energy $\mathrm{Q}$ to be removed from the PV module by the suggested cooling method. This thermal energy to be removed and the latent heat, $\lambda$ of RT35 on an hourly basis are equal[49]. Thus,

$Q=m \times \lambda$, where $m$ is the mass $(\mathrm{kg})$ of the PCM.

$81.729 \times 3600=m \times 160000$

$m=1.84 \mathrm{~kg}$ per hour.

The volume of the PCM,

$$
v=\operatorname{mass}(m) / R T 35 \text { solid state density. }
$$$$
v=1.84 / 860=2.14 \times 10^{-3} \mathrm{~m}^{3} \text { per hour. }
$$

\section{Conclusion}

In this paper, a comparative study of the thermal performance of four solar module configurations was analyzed based on the solar irradiation of Uganda. The studied 
solar module configurations included a conventional PVT module, a coupled PV with PCM material PVT/PCM-I, a PV coupled with internally finned PCM, PVT/PCM-II, and a combined cooling effect of the PCM and a cooling duct coupled onto a PV module, PVT/PCM-III. A detailed thermal analysis was carried out through various thermal parameters and governing equations. From the study, the following inferences can be drawn:

- Application of a cooling duct as seen in PVT/PCM-III contributes minimal increases in efficiency but allows for the cooling of the rear end of the PCM which increases the system's effectiveness in an excessively hot environment.

- When the temperature of the ambient air is lower than the melting temperature, the system's effectiveness is high while in areas where the ambient air temperature is equal to or slightly higher than the melting temperature of the PCM systems modifications are required to cool the incoming cooling air.

\section{References}

[1] S. F. Jaber and A. M. Shakir, "Design and Simulation of a Boost-Microinverter for Optimized Photovoltaic System Performance," vol. 5, no. 2, 2021.

[2] IRENA, “A Renewable Energy Roadmap Report," Irena, no. June, p. 173, 2014.

[3] M. E. Shayan and G. Najafi, "Energy-Economic Optimization of Thin Layer Photovoltaic on Domes and Cylindrical Towers," vol. 3, no. 2, 2019.

[4] A. Harrouz, M. Abbes, I. Colak, and K. Kayisli, "Smart grid and renewable energy in Algeria," vol. 5, pp. 11661171, 2017, doi: 10.1109/icrera.2017.8191237.

[5] O. Aboelwafa, S. E. K. Fateen, A. Soliman, and I. M. Ismail, "A review on solar Rankine cycles: Working fluids, applications, and cycle modifications," Renew. Sustain. Energy Rev., vol. 82, no. February, pp. 868-885, 2018, doi: 10.1016/j.rser.2017.09.097.

[6] B. Twomey, P. A. Jacobs, and H. Gurgenci, "Dynamic performance estimation of small-scale solar cogeneration with an organic Rankine cycle using a scroll expander," Appl. Therm. Eng., vol. 51, no. 1-2, pp. 1307-1316, 2013, doi: 10.1016/j.applthermaleng.2012.06.054.

[7] N. Savvakis and T. Tsoutsos, "Theoretical design and experimental evaluation of a PV+PCM system in the mediterranean climate," Energy, vol. 220, p. 119690, 2021, doi: 10.1016/j.energy.2020.119690.

[8] K. Ranabhat, L. Patrikeev, A. A. evna Revina, K. Andrianov, V. Lapshinsky, and E. Sofronova, "An introduction to solar cell technology," J. Appl. Eng. Sci., vol. 14 , no. 4, pp. 481-491, 2016, doi: 10.5937/jaes1410879 .

[9] A. A and N. John, "Performance Evaluation of On-Grid and Off-Grid Solar Photovoltaic Systems," Ijireeice, no. March, pp. 20-23, 2015, doi: 10.17148/ijireeice.2015.3205.

[10] D. A. Quansah, M. S. Adaramola, and L. D. Mensah, "Solar Photovoltaics in Sub-Saharan Africa - Addressing Barriers, Unlocking Potential," Energy Procedia, vol. 106, pp. 97-110, 2016, doi: 10.1016/j.egypro.2016.12.108.

[11] T. Saga, "Advances in crystalline silicon solar cell technology for industrial mass production," NPG Asia
Mater., vol. 2, no. 3, pp. 96-102, 2010, doi: 10.1038/asiamat.2010.82.

[12] M. Tucci and M. Izzi, "High efficiency monocrystalline silicon solar cells: reaching the theoretical limit," no. August, pp. 745-763, 2013.

[13] E. Skoplaki and J. A. Palyvos, "On the temperature dependence of photovoltaic module electrical performance: A review of efficiency/power correlations," Sol. Energy, vol. 83, no. 5, pp. 614-624, 2009, doi: 10.1016/j.solener.2008.10.008.

[14] N. Boulfaf, J. Chaoufi, A. Ghafiri, and A. Elorf, "Thermal study of hybrid photovoltaic thermal (PV-T) solar air collector using finite element method," Int. J. Renew. Energy Res., vol. 6, no. 1, pp. 171-182, 2016.

[15] T. A. Salaoru, M. Andrei, M. D. Roman, "treatment Modelling of systems with multiple energy carriers in buildings Numerical study of air cooling photovoltaic panels using heat sinks," 2016.

[16] A. I. A. AL-Musawi, A. Taheri, A. Farzanehnia, M. Sardarabadi, and M. Passandideh-Fard, "Numerical study of the effects of nanofluids and phase-change materials in photovoltaic thermal (PVT) systems," J. Therm. Anal. Calorim., vol. 137, no. 2, pp. 623-636, 2019, doi: 10.1007/s10973-018-7972-6.

[17] H. A. Nasef, S. A. Nada, and H. Hassan, "Integrative passive and active cooling system using PCM and nanofluid for thermal regulation of concentrated photovoltaic solar cells," Energy Convers. Manag., vol. 199, no. September, p. 112065, 2019, doi: 10.1016/j.enconman.2019.112065.

[18] A. Royne, C. J. Dey, and D. R. Mills, "Cooling of photovoltaic cells under concentrated illumination: A critical review," Sol. Energy Mater. Sol. Cells, vol. 86, no. 4, pp. 451-483, 2005, doi: 10.1016/j.solmat.2004.09.003.

[19] K. Araki, H. Uozumi, and M. Yamaguchi, "A simple passive cooling structure and its heat analysis for $500 \mathrm{X}$ concentrator PV module," Conf. Rec. IEEE Photovolt. Spec. Conf., pp. 1568-1571, 2002, doi: 10.1109/pvsc.2002.1190913.

[20] M. R. Shaeri and R. W. Bonner, "Analytical heat transfer model for laterally perforated-finned heat sinks," Int. J. Heat Mass Transf., vol. 131, pp. 1164-1173, 2019, doi: 10.1016/j.ijheatmasstransfer.2018.11.138.

[21] https://ocw.mit.edu (last accessed on 12/12/2021)

[22] Hari Raghavan J and Rangu P, "A Study and Analysis on the Thermal Performance of a Pin Fin Heatsink for Natural Convection using CFD," Int. J. Eng. Res., vol. V6, no. 05, 2017, doi: 10.17577/ijertv6is050563.

[23] A. Uday Kumar, A. Javed, and S. K. Dubey, "Material Selection for Microchannel Heatsink: Conjugate Heat Transfer Simulation," IOP Conf. Ser. Mater. Sci. Eng., vol. 346, no. 1, 2018, doi: 10.1088/1757-899X/346/1/012024.

[24] A. Soni, "Study of Thermal Performance between Plate-fin, Pin-fin and Elliptical Fin Heat Sinks in Closed Enclosure under Natural Convection," Int. Adv. Res. J. Sci. Eng. Technol. ISO, vol. 3297, no. 11, pp. 133-139, 2007, doi: 10.17148/IARJSET.2016.31126.

[25] M. I. Hasan, A. M. A. R. Rageb, and M. Yaghoubi, "Investigation of a Counter Flow Microchannel Heat Exchanger Performance with Using Nanofluid as a Coolant," J. Electron. Cool. Therm. Control, vol. 02, no. 
03, pp. 35-43, 2012, doi: 10.4236/jectc.2012.23004.

[26] M. A. Taher and M. N. Fares, "Experimental investigation of solar energy storage using paraffin wax as thermal mass," Int. J. Renew. Energy Res., vol. 7, no. 4, pp. 1752-1766, 2017.

[27] P. Ruano, L. L. Delgado, S. Picco, "We are IntechOpen, the world' $\mathrm{s}$ leading publisher of Open Access books Built by scientists, for scientists TOP $1 \%$," Intech, no. tourism, p. 13, 2016.

[28] K. A. Thakare, A. G. Bhave, "Review on Latent Heat Storage and Problems Associated With Phase Change Materials," Int. J. Res. Eng. Technol., vol. 04, no. 10, pp. 176-182, 2015, doi: 10.15623/ijret.2015.0410030.

[29] B. Kamkari, H. Shokouhmand, and F. Bruno, "Experimental investigation of the effect of inclination angle on convection-driven melting of phase change material in a rectangular enclosure," Int. J. Heat Mass Transf., vol. 72, pp. 186-200, 2014, doi: 10.1016/j.ijheatmasstransfer.2014.01.014.

[30] T. Nehari, M. Benlekkam, D. Nehari, and A. Youcefi, "The effect of inclination on the passive cooling of the solar PV panel by using phase change material," Int. J. Renew. Energy Res., vol. 6, no. 1, pp. 1434-1441, 2016.

[31] R. Velraj, R. V. Seeniraj, B. Hafner, C. Faber, and K. Schwarzer, "Heat transfer enhancement in a latent heat storage system," Sol. Energy, vol. 65, no. 3, pp. 171-180, 1999, doi: 10.1016/S0038-092X(98)00128-5.

[32] Z. Arifin, D. D. D. P. Tjahjana, S. Hadi, R. A. Rachmanto, G. Setyohandoko, and B. Sutanto, "Numerical and experimental investigation of air cooling for photovoltaic panels using aluminum heat sinks," Int. J. Photoenergy, vol. 2020, 2020, doi: $10.1155 / 2020 / 1574274$.

[33] S. A. Nada, D. H. El-Nagar, and H. M. S. Hussein, "Improving the thermal regulation and efficiency enhancement of PCM-Integrated PV modules using nano particles," Energy Convers. Manag., vol. 166, no. January, pp. 735-743, 2018, doi: 10.1016/j.enconman.2018.04.035.

[34] M. J. Huang, P. C. Eames, B. Norton, and N. J. Hewitt, "Natural convection in an internally finned phase change material heat sink for the thermal management of photovoltaics," Sol. Energy Mater. Sol. Cells, vol. 95, no. 7, pp. 1598-1603, 2011, doi: 10.1016/j.solmat.2011.01.008.

[35] https://www.rubitherm.eu (last accessed on $12 / 12 / 2021)$

[36] D. Okello, J. Mubiru, and E. J. K. Banda, “Availability of direct solar radiation in Uganda," 30th ISES Bienn. Sol. World Congr. 2011, SWC 2011, vol. 5, pp. 3554-3563, 2011, doi: 10.18086/swc.2011.24.22.

[37] B. Niezgoda-Zelasko, "The Enthalpy-porosity Method Applied to the Modelling of the Ice Slurry Melting Process during Tube Flow," Procedia Eng., vol. 157, pp. 114-121, 2016, doi: 10.1016/j.proeng.2016.08.346.

[38] M. Emam, S. Ookawara, and M. Ahmed, "Performance study and analysis of an inclined concentrated photovoltaic-phase change material system," vol. 150, pp. 229-245, 2017.

[39] C. Hajjaj, M. Benhmida, R. Bendaoud, “A PVT cooling system design and realization: Temperature effect on the PV module performance under real operating conditions,"
Int. J. Renew. Energy Res., vol. 9, no. 1, pp. 401-413, 2019.

[40] H. A. Nasef, S. A. Nada, and H. Hassan, "Integrative passive and active cooling system using PCM and nano fl uid for thermal regulation of concentrated photovoltaic solar cells," vol. 199, no. June, 2019.

[41] H. Shmueli, G. Ziskind, and R. Letan, "Melting in a vertical cylindrical tube: Numerical investigation and comparison with experiments," Int. J. Heat Mass Transf., vol. 53, no. 19-20, pp. 4082-4091, 2010, doi: 10.1016/j.ijheatmasstransfer.2010.05.028.

[42] M. E. A. Slimani, M. Amirat, I. Kurucz, S. Bahria, A. Hamidat, and W. B. Chaouch, "A detailed thermalelectrical model of three photovoltaic/thermal (PV/T) hybrid air collectors and photovoltaic (PV) module: Comparative study under Algiers climatic conditions," Energy Convers. Manag., vol. 133, pp. 458-476, 2017, doi: 10.1016/j.enconman.2016.10.066.

[43] S. Dubey, J. N. Sarvaiya, and B. Seshadri, "Temperature dependent photovoltaic (PV) efficiency and its effect on PV production in the world - A review," Energy Procedia, vol. 33, pp. 311-321, 2013, doi: 10.1016/j.egypro.2013.05.072.

[44] P. Raghuraman, "Design considerations for flat-platephotovoltaic/thermal collectors," vol. 35 , no. 3, pp. 227 $241,1985$.

[45] H. G. Teo, P. S. Lee, and M. N. A. Hawlader, "An active cooling system for photovoltaic modules," Appl. Energy, vol. 90, no. 1, pp. 309-315, 2012, doi: 10.1016/j.apenergy.2011.01.017.

[46] A. Radwan, S. Ookawara, and M. Ahmed, "Analysis and simulation of concentrating photovoltaic systems with a microchannel heat sink," Sol. Energy, vol. 136, pp. 3548, 2016, doi: 10.1016/j.solener.2016.06.070.

[47] M. Sardarabadi, M. Passandideh-fard, M. Maghrebi, and M. Ghazikhani, "crossmark," vol. 161, no. November 2016, pp. 2-69, 2017.

[48] S. Cho, M. H. Shin, Y. K. Kim, "Effects of infrared radiation and heat on human skin aging in vivo," $J$. Investig. Dermatology Symp. Proc., vol. 14, no. 1, pp. 1519, 2009, doi: 10.1038/jidsymp.2009.7.

[49] G. TK and V. Raj, "Use of phase change material (PCM) for the improvement of thermal performance of cold storage," MOJ Curr. Res. Rev., vol. 1, no. 2, pp. 4961, 2018, doi: 10.15406/mojcrr.2018.01.00010.

[50] M. Sardarabadi, M. Passandideh-Fard, M. J. Maghrebi, and M. Ghazikhani, "Experimental study of using both $\mathrm{ZnO}$ / water nanofluid and phase change material (PCM) in photovoltaic thermal systems," Sol. Energy Mater. Sol. Cells, vol. 161, no. November 2016, pp. 62-69, 2017, doi: 10.1016/j.solmat.2016.11.032. 